\title{
Vulnerability Assessment of Landslide Areas in Ci Manuk Upstream Watershed, Garut District, West Java Province
}

\author{
Muhammad Edgar Fauzan ${ }^{\# 1}$, Astrid Damayanti ${ }^{\# 2}$, Ratna Saraswati ${ }^{\# 3}$ \\ ${ }^{*}$ Department of Geography, Universitas Indonesia, Beji, Depok, 16424, Indonesia \\ E-mail: ${ }^{1}$ edgarfauzan@gmail.com; ${ }^{2}$ astrid.damayanti@sci.ui.ac.id; ${ }^{3}$ ratna.saraswati77@gmail.com
}

\begin{abstract}
Landslide is challenging to detect and predict. Settlements are not always located on ideal land according to designated areas, such as settlements in a landslide area. Ci Manuk Upstream watershed, Garut District, West Java Province, has critical land due to human intervention. The environment is more sensitive to the components in the environmental system, so when it rains, landslide disasters are prone to happen. This study aims to predict and analyze the vulnerability settlement of landslide in Ci Manuk Upstream watershed, Garut District, West Java Province. The research method is done gradually, beginning with using Stability Index Mapping (SINMAP) method to generate a landslide potential area, then using a spatial analysis method to determine the landslide-prone area and finally assessing the vulnerability of the settlements in the landslide area. The results show that $43.88 \%$ of the total area is a potential landslide area, then $19.04 \%$ is a high landslide-prone area, and $30.80 \%$ is the vulnerability of the settlement areas in the high landslide area. This study also shows that the landslide potential area is dominant at slope $>25 \%$, dystrudept soil type, and rainfall rate of $>3500 \mathrm{~mm} / \mathrm{year}$. The landslide-prone settlement areas tend to be in the landslide zone of SINMAP modeling, and vulnerable settlements have tended to be south of the watershed because of the low quality of buildings and high population densities.
\end{abstract}

Keywords — landslide; settlement; SINMAP; vulnerability.

\section{INTRODUCTION}

Landslide is challenging to detect and predict. Settlements are not always on the ideal land following predetermined land use, for example, in a landslide area. In Indonesia, there are 573 incidents for landslide disaster of 2,163 total disaster incidents occurring from 1 January to 31 December 2017 [1]. The occurrence of the landslide caused 109 deaths, 150 injured, 46,326 people displaced, and 1,651 damaged houses consisting of 585 heavily damaged, 403 moderately damaged, and 663 slightly damaged [1]. This is because of the topography in Indonesia mostly has steep slopes and very fertile soils, hence why the community often utilize the land for agricultural activities without thinking about the risk of disasters that occur due to the land clearing on the slopes [2].

The slope is not the only factor causing landslide disaster, but physical factors and social factors can also influence the occurrence of landslide disaster [3]. Physical considerations include slope, rainfall rate, and geological conditions in the area. Social factors in the form of human activities can also affect the landslide disaster, such as land use in the form of settlements [4].
There are 22 districts or cities in West Java that vulnerable to landslide, and one of them is Garut Regency [5]. The area of Garut is located at the Ci Manuk Upstream and in the southern province of West Java. Active volcanoes surround it. The general condition of the land topography is bumpy, hilly, mountainous, thick weathered soil, and supported by a high rainfall rate that is accumulative [6]. The topography makes the region very prone to landslide disaster.

Most areas that have a high category in landslide disasters are in the Ci Manuk Upstream area [7]. Administratively in 2016, landslide potential occurs in Ci Manuk Upstream, covering 21 sub-districts and spread over 121 villages/locations with a total area of $53.61 \mathrm{~km} 2$. Ci Manuk Upstream has a critical land since 1984 by getting more damage by human interventions [8]. As a response from this watershed damage, the environment becomes increasingly sensitive to existing components in the environmental system, so when the rain happens, it is easy for a landslide to occur [9].

Identification and prediction of potential landscape and vulnerability of landslides can be done quickly by using Geographic Information System [10]. GIS will facilitate the analysis and presentation of spatial information, especially related to the determination of potential areas and 
vulnerability level of landslide disaster [11]. This research is expected to be useful for the community to recognize areas vulnerable to landslides and to provide information to the local governments to facilitate mitigation in the regions that are vulnerable to landslides.

Research on potential landslides with SINMAP method has been widely used. Deb and El-Kadi, with his research Susceptibility assessment of shallow landslides on Oahu, Hawaii, under extreme-rainfall events. This study was conducted on an area of 38,400 hectares divided into four regions based on soil type and hydrological characteristics. Deb uses data in the form of the Digital Elevation Model (DEM), soil type, and soil characteristics used as parameters in SINMAP, hydrological data in the form of rainfall, and landslide events from 1949 to 2006 [12].

Andriono studied the vulnerable area of the landslide in Ci Tarik Sukabumi District. This research uses a descriptive approach to the SINMAP method. Researchers use altitude data in the form of a Digital Elevation Model (DEM) compiled with physical variables of soil type, cohesion, friction angle, and soil Moisture index (T/R) and climate data in the form of rainfall. Furthermore, the potential area of landslides in an overlay with residential spatial data and avalanche event data (fact) [13].

Then, Wibowo, with the title identification of landslide vulnerable in Cicalengka sub-district, Bandung Regency. This research uses the SINMAP modeling method. The data used is Rupa Bumi Indonesia (RBI) map, land type map, land use map and cohesion data of Internal friction angle $(\Phi)$, $\mathrm{T} / \mathrm{R}$ which obtained from research result of Department of Soil Science Erosion Control and Land Conservation, Institute of Soil Science and Plant Cultivation in Pulawy, Poland [14].

The objective of the study is to analyze the distribution of potential areas to landslides in $\mathrm{Ci}$ Manuk Upstream Watershed, analyzing the distribution of settlement areas are prone to landslides in Ci Manuk Upstream Watershed and analyzing the distribution of vulnerable settlements in high landslide area in $\mathrm{Ci}$ Manuk Upstream Watershed, Garut District, West Java Province.

\section{MATERIAL AND METHOD}

SINMAP modeling (Stability Index Mapping) is used to determine the landslide vulnerable settlement areas [15]. Variables used include slope, soil type, and rainfall rate. Determination of landslide disaster potential areas is performed by using the SINMAP method by entering cohesion, angle friction, and ratio of transmissivity to effective recharge $(T / R)$ value and validated by landslide occurrence point (fact). Furthermore, landslide-prone areas are determined by overlaying land-use variables in the form of settlements with landslide potential areas. The landslide vulnerable settlement areas are determined by using overlay methods of physical and social vulnerability variables, which are building quality and population density. Systematically, SINMAP method has the equation to set the Stability Index (SI) slope is as follows [16]:

$$
S I=F S=\frac{C+\cos \theta\left[1-\min \left(\frac{R \alpha}{T \sin \theta}, 1\right) r\right] \tan \phi}{\sin \theta}
$$

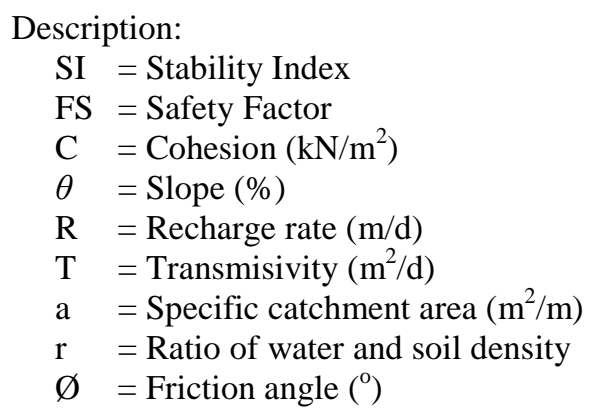

TABLE I

VARIABLES AND SOURCES

\begin{tabular}{|c|l|l|}
\hline No. & \multicolumn{1}{|c|}{ Variable } & \multicolumn{1}{c|}{ Source } \\
\hline 1 & $\begin{array}{l}\text { Rupa Bumi Indonesia (RBI) } \\
\text { Map scale 1:25.000 }\end{array}$ & $\begin{array}{l}\text { Badan Informasi Geospasial } \\
\text { (BIG) }\end{array}$ \\
\hline 2 & $\begin{array}{l}\text { Precipitation Ci Manuk in } \\
2010-2016 \text { scale 1:50.000 }\end{array}$ & $\begin{array}{l}\text { Balai Pengelola Daerah } \\
\text { Aliran Sungai Ci Manuk - Ci } \\
\text { Tanduy and Dinas Pekerjaan } \\
\text { Umum dan Penataan Ruang }\end{array}$ \\
\hline 3 & Soil type scale 1:50.000 & $\begin{array}{l}\text { Balai Besar Litbang } \\
\text { Sumberdaya Lahan } \\
\text { Pertanian (BBSDLP) }\end{array}$ \\
\hline 4 & Slope scale 1:25.000 & $\begin{array}{l}\text { Digital Elevation Model } \\
\text { (DEM) }\end{array}$ \\
\hline 5 & Land use scale 1:25.000 & $\begin{array}{l}\text { Peta Rupa Bumi Indonesia } \\
\text { (RBI) from Badan Informasi } \\
\text { Geospasial (BIG) }\end{array}$ \\
\hline 6 & Landslide events (fact) in & $\begin{array}{l}\text { Badan Penanggulangan } \\
\text { Bencana Daerah (BPBD) } \\
\text { and survey }\end{array}$ \\
\hline 7 & Building quality & Survey \\
\hline 8 & Population density in 2017 & Badan Pusat Statistik (BPS) \\
\hline
\end{tabular}

The data needed for this research are spatial and tabular, as well as other supporting data obtained from related institutions, such as Badan Nasional Penanggulangan Bencana (BNPB), Badan Pusat Statistik (BIG) and Badan Informasi Geospatial (BIG). Besides, direct observations in the field are also conducted to test the validation of the landslide point and data quality building. In determining the area of landslide potential in $\mathrm{Ci}$ Manuk Upstream, data processing is needed with variables of the slope, soil type, and rainfall rate using SINMAP method to obtain landslide disaster potential area and validation with the landslide occurrence point (fact) [17]. Then, to determine the landslide-prone residential areas, it is necessary to use landuse variables in the form of settlements overlaid with potential landslide areas, then the overlay results will result in landslide-prone regions [18]. Then, the variables of physical and social vulnerability are building quality and population density, which then analyzed overlay again with the landslide-prone area, so that will get the result of vulnerable landslide areas in the $\mathrm{Ci}$ Manuk Upstream area [19]. These are the data and sources used in Table 1. 
Model accuracy in predicting potential avalanches will need to be tested for success levels. One of the recent validations is knowing the number of landslides that occur in the model slope stability class. Modeling based on the study indicates that mudslides occur markedly in a type of unstable slopes [20]. Modeling results are good when most of the data for incidents of low avalanches are in a class of potential small slides to a potential high landslide [21]. Systematically, the number of landslides in the region is not stable, divided by the total number of landslides times $100 \%$.

\section{RESULTS AND DISCUSSION}

\section{A. Landslide Potential Areas in Ci Manuk Upstream Watershed Based on SINMAP}

The output of SINMAP modeling resulted in Stability Index in the form of raster data [22]. Which are then classified into six classes; stable, moderately stable, quasistable, lower threshold, upper threshold, and defended landslide potential [10]. These classes are based on the Stability Index (SI) SINMAP in Table 2 [23]. In this study, stable, moderately stable and quasi-stable classified into one stable class. Ci Manuk Upstream Watershed is dominated by a stable area of $817.54 \mathrm{~km}^{2}$ or about $56.12 \%$, and the rest around $639.23 \mathrm{~km}^{2}$ or $43.88 \%$, which indicates the area that may occur landslide (Low, Moderate, and High landslide potential). SINMAP modeling in this study area has an accuracy of $81.57 \%$.
TABLE III

AREA of LANDSLIDE Potential of Ci MANUK UPSTREAM WATERSHED

\begin{tabular}{|c|l|c|c|}
\hline \multirow{2}{*}{ No. } & \multicolumn{1}{|c|}{ Class } & \multicolumn{2}{|c|}{ Area } \\
\cline { 3 - 4 } & & $\mathbf{k m}^{\mathbf{2}}$ & $\mathbf{\%}$ \\
\hline 1 & Stable (SI >1.5) & 671.13 & 46.07 \\
\hline 2 & $\begin{array}{l}\text { Moderately Stable (1.5 > SI > } \\
1.25)\end{array}$ & 59.93 & 4.11 \\
\hline 3 & Quasi-Stable (1.25 > SI > 1.0) & 86.48 & 5.94 \\
\hline 4 & Lower Threshold (1.0 > SI > 0.5) & 327.40 & 22.47 \\
\hline 5 & Upper Threshold (0.5 > SI > 0.0) & 74.87 & 5.14 \\
\hline 6 & Defended (0.0 > SI) & 236.96 & 16.27 \\
\hline Total & & 1456.77 & 100.00 \\
\hline
\end{tabular}

\section{B. Validation of Landslide Potential Area}

The location of landslides in $\mathrm{Ci}$ Manuk Upstream Watershed is sourced from Badan Penanggulangan Bencana Daerah (BPBD) 2016 to 2017 with the number of landslide incidents as many as 38 points and spread in 33 villages. Landslides occur in villages of Sukahurip, Barusuda, Sukarame (Cilawu Subdistrict), Cintanagara, Penyembong, Mulyasari, Karyamukti, Cipangramatan, Mekarsari, Mangkurakyat, Ngamplang, Karyamekar, Sukamulya, Padamukti, Sukatani, Karamatwangi, Sukanegla, Sukamatri, Kotawetan, Hegarsari, Sukarame (Leles Subdistrict), Jangkurang, Haruman, Leles, Karanganyar, Pakenjeng, Padaawas, Caringin, Cinta, Cintamanik, Jayawaras, Sukajadi, and Cimanganten (Fig 1).

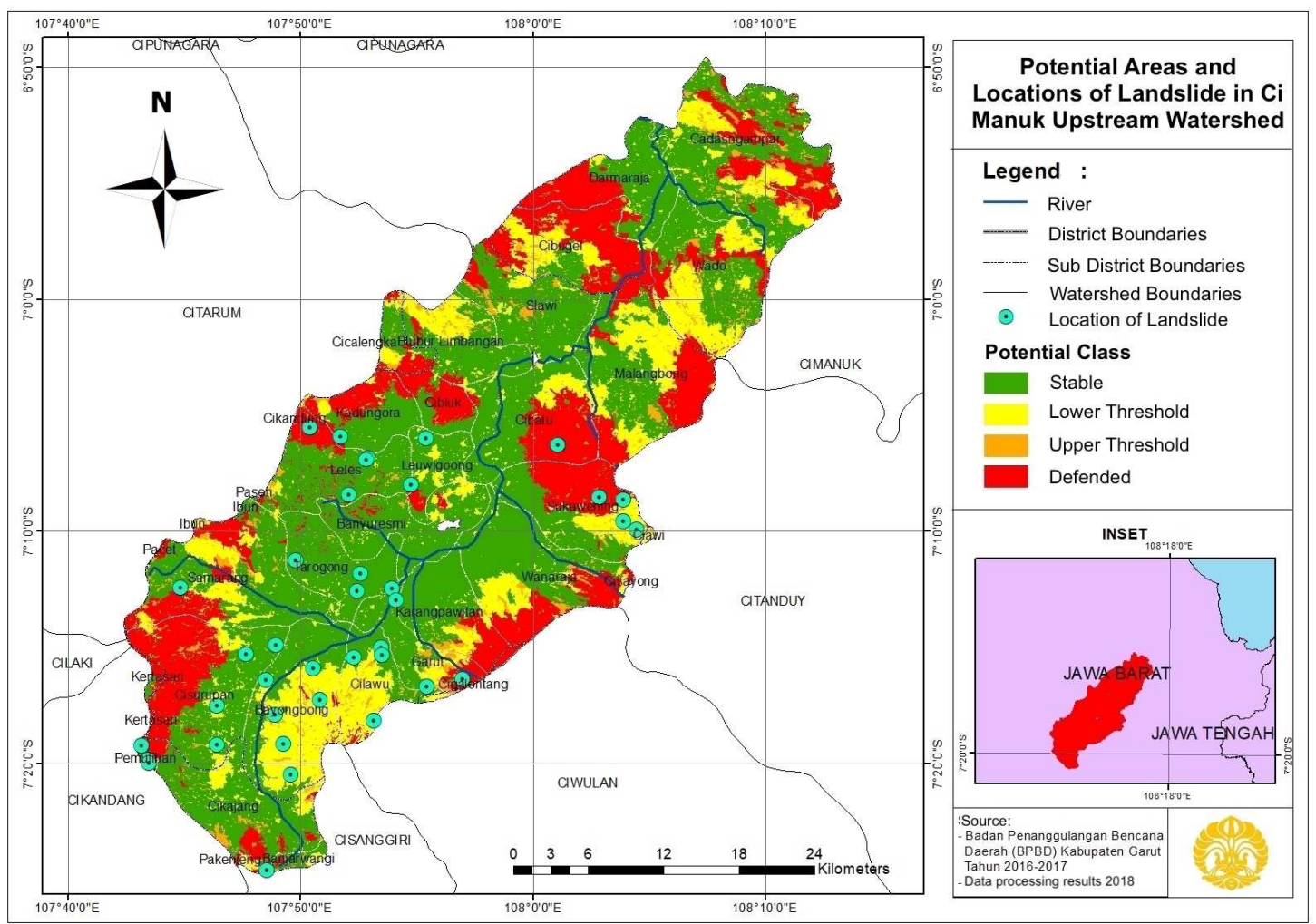

Fig. 1 Potential Areas and Locations of Landslide in Ci Manuk Upstream Watershed Based on SINMAP

The location point of the landslide event is used to check the accuracy of the SINMAP modeling results by the overlay method. The overlay result of landslide occurrence location with landslide potential area (stability index) shows that there are 7 points of landslide occurrence that are in relatively stable area or not having any landslide potential, while 31 points of landslide occurrence are in landslideprone area with Low, Moderate, and High class (Fig 2) and the levels are in Table 3. 


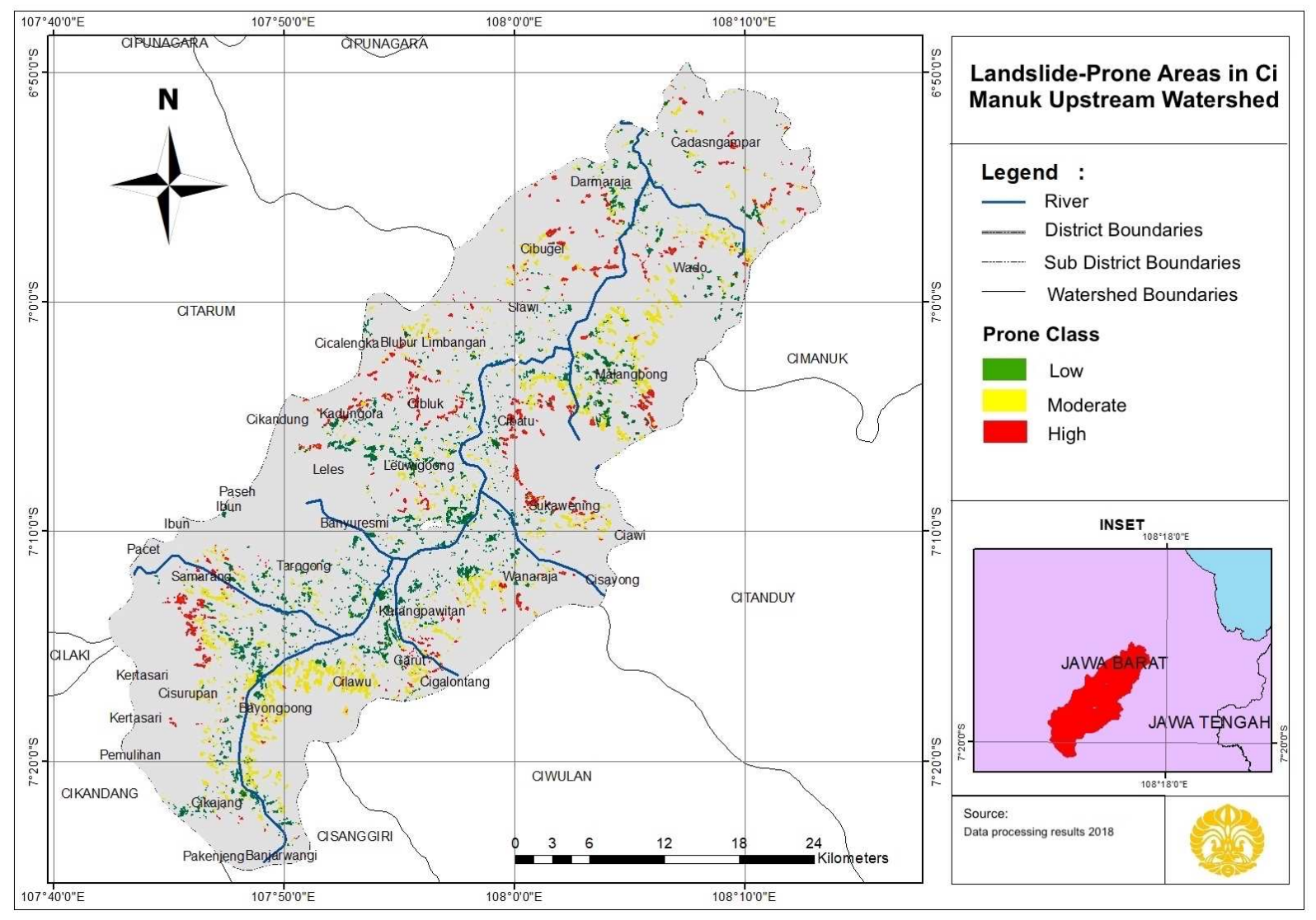

Fig. 2 Landslide-Prone Areas in Ci Manuk Upstream Watershed

\section{Landslide-Prone Areas in Ci Manuk Upstream Watershed.}

The landslide-prone areas in $\mathrm{Ci}$ Manuk Upstream Watershed have a total area of $66.70 \mathrm{~km}^{2}$. The landslideprone regions are generated from an overlay between the landslide potential area and the residential area. Most of the area is in an area with a slope of $>25 \%$. Landslide-prone areas are divided into three classes, namely Low landslideprone, Moderate landslide-prone, and High landslide-prone. The distribution of the landslide-prone regions in $\mathrm{Ci}$ Manuk Upstream Watershed can be seen in Fig 2. In the southern or Upstream watershed, the landslide-prone areas are dominated by Low and Moderate classes $\left(29.70 \mathrm{~km}^{2}\right.$ or $44.53 \%$ ), while in the downstream basin, it is dominated by High-class areas $\left(12.70 \mathrm{~km}^{2}\right.$ or $\left.19.04 \%\right)$. In the downstream basin, the areas are dominated by Low and High landslideprone. The extent and percentage of each vulnerable class can be seen in Table 3 .

TABLE IIII

AREA AND PERCENTAges OF LANDSLIDE-PRONE AREAS Ci MANUK UPSTREAM WATERSHED

\begin{tabular}{|c|l|c|c|}
\hline No. & \multicolumn{1}{|c|}{ Class } & $\begin{array}{r}\text { Area } \\
\left(\mathbf{k m}^{\mathbf{2}}\right)\end{array}$ & $\begin{array}{c}\text { Percentage } \\
\mathbf{( \% )}\end{array}$ \\
\hline 1 & Low (SI > 1.0) & 24.29 & 36.42 \\
\hline 2 & Moderate $(1.0>$ SI $>0.0)$ & 29.70 & 44.53 \\
\hline 3 & High $(0.0>$ SI) & 12.70 & 19.04 \\
\hline \multicolumn{2}{|c|}{ Total } & 66.70 & 100.00 \\
\hline
\end{tabular}

The extent of landslide-prone areas is smaller than the landslide potential area. Most of the landslide potential areas are in non-residential land use areas, causing most landslide potential areas not to become landslide-prone areas. Fig 3 shows a description of the highly damaged area of landslides in Cibatu District, Karyamukti Village, Kampung Karoya taken using Google Earth software. Cibatu District has a steep slope, so in this area, it is very prone to landslides.

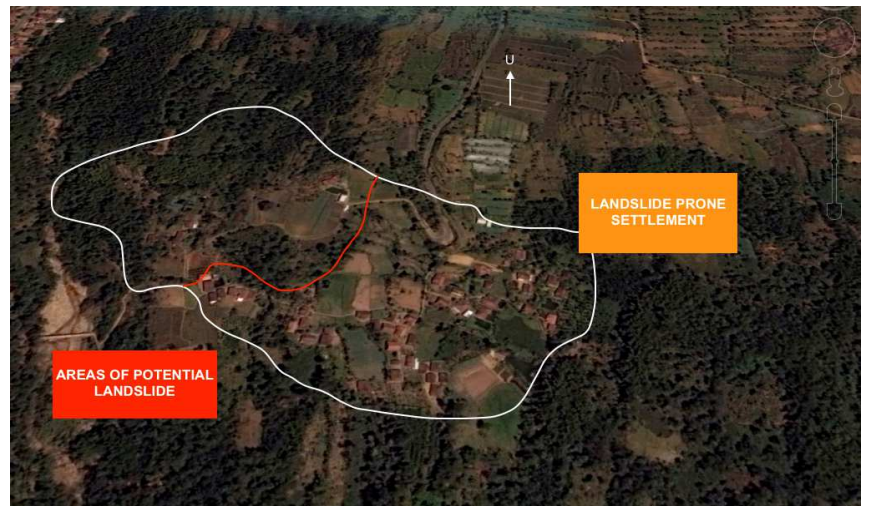

Fig. 3 Landslide-Prone Areas in Ci Manuk Upstream Watershed from Google Earth

\section{Building Quality in Ci Manuk Upstream Watershed}

Building quality is one of the variables to determine the vulnerability of the landslide area in this study. The research area is dominated by permanent building quality with an area of $34.83 \mathrm{~km}^{2}$ or $52.22 \%$ (Fig 4). 


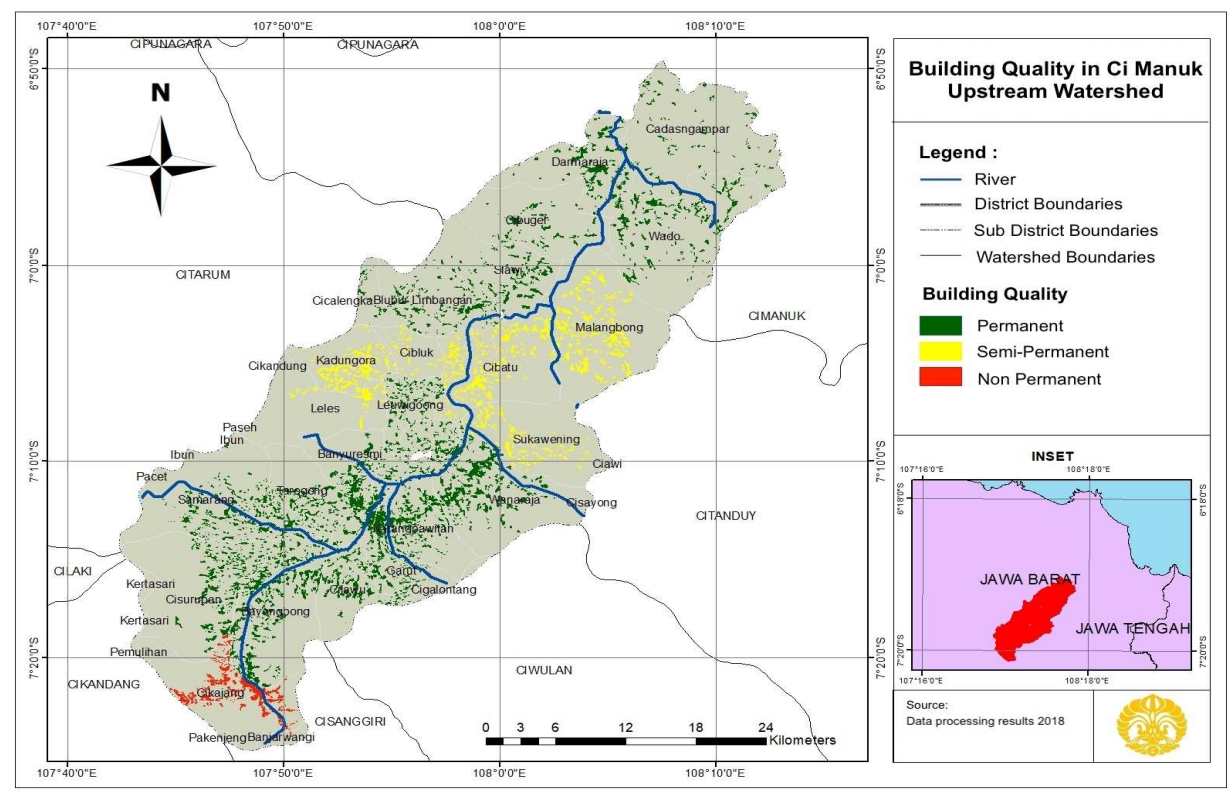

Fig. 4 Building Quality in Ci Manuk Upstream Watershed

In the middle of the watershed is a semi-permanent building (half-bamboo and half-cement). In the south or Upstream of the watershed, there are areas with non- permanent building quality (all still using bamboo). Table 4 shows the extent and percentage of building quality for each class based on building materials [24].

TABLE IV

AREA AND PERCENTAge of BuILDing Quality Class of Ci MANuK UpSTREAM Watershed

\begin{tabular}{|c|l|c|c|}
\hline No. & Building Quality Class of Landslide & Area $\mathbf{( k m}^{2}$ ) & Percentage (\%) \\
\hline 1 & Permanent (Cement) & 34.83 & 52.22 \\
\hline 2 & Semi-Permanent (Half-bamboo half-cement) & 25.43 & 38.13 \\
\hline 3 & Non-Permanent (Bamboo) & 6.43 & 9.65 \\
\hline Total & 66.70 & 100.00 \\
\hline
\end{tabular}

\section{E. Population Density in Ci Manuk Upstream Watershed}

Classification of population density data is needed to determine the vulnerability of landslides, (Fig 5). Based on
Fig 5, the population density in $\mathrm{Ci}$ Manuk Upstream Watershed tends to be high in the Upstream areas marked by dark color symbols.

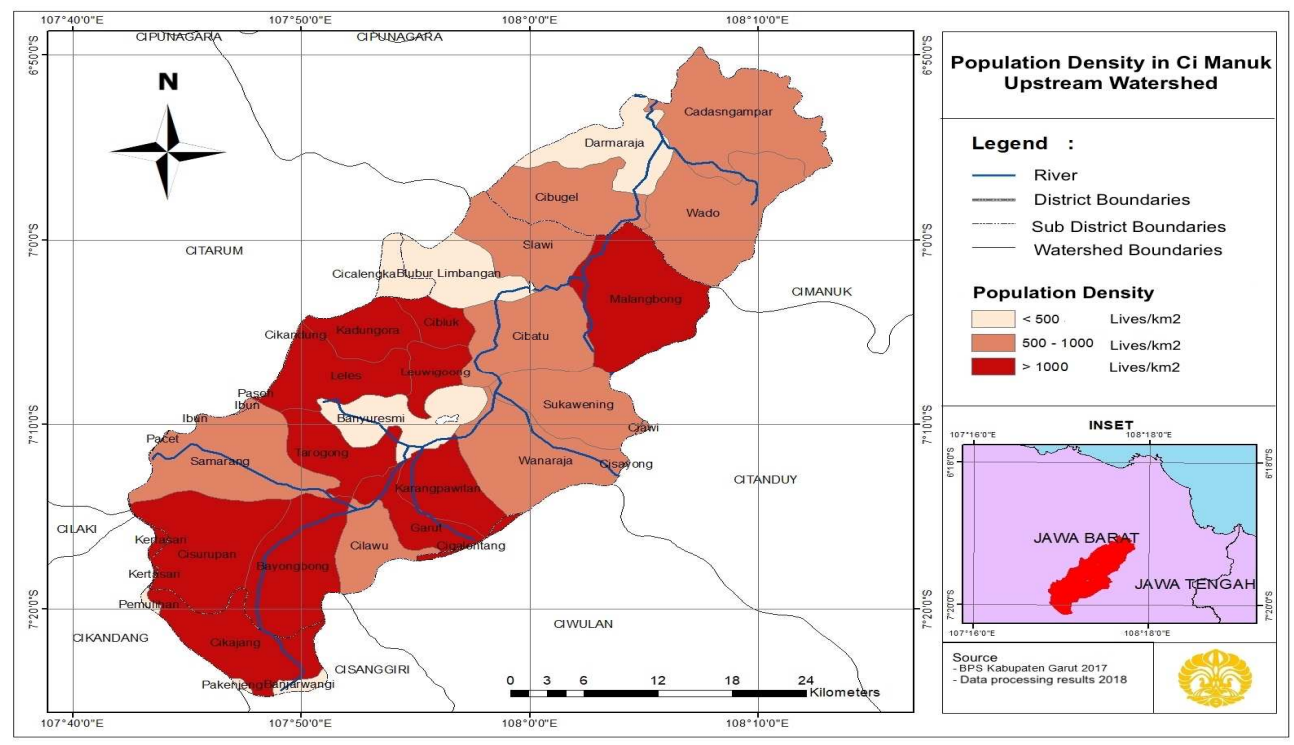

Fig. 5 Population Density in Ci Manuk Upstream Watershed

Then, in the middle to the north or downstream, the watershed is dominated by a symbol with a bright gradation color, which indicates a low and medium density population.
The determination of vulnerability class based on population density can be seen in Table 5 . 
TABLE IV

LANDSLIDE VULNERABILITY ClaSS BASED ON POPULATION DENSITY IN CI MANUK UPSTREAM WATERSHED

\begin{tabular}{|c|c|c|}
\hline District & $\begin{array}{l}\text { Population Density } \\
\left(\text { Lives } / \mathbf{k m}^{2}\right)\end{array}$ & $\begin{array}{c}\text { Vulnerability } \\
\text { Class }\end{array}$ \\
\hline Pakenjeng & 459.32 & Low \\
\hline Pamulihan & 497.70 & Low \\
\hline Cikajang & 1112.97 & High \\
\hline Banjarwangi & 340.88 & Low \\
\hline Cilawu & 578.77 & Moderate \\
\hline Bayongbong & 1116.60 & High \\
\hline Cisurupan & 1032.20 & High \\
\hline Samarang & 810.30 & Moderate \\
\hline Tarogong & 2443.36 & High \\
\hline Garut & 3838.86 & High \\
\hline Karangpawitan & 2516.33 & High \\
\hline Wanaraja & 500.58 & Moderate \\
\hline Sukawening & 766.45 & Moderate \\
\hline Leles & 1280.19 & High \\
\hline Leuwigoong & 1731.43 & High \\
\hline Kadungora & 2362.26 & High \\
\hline Cibiuk & 1512.35 & High \\
\hline Cibatu & 886.48 & Moderate \\
\hline Malangbong & 1150.25 & High \\
\hline Blubur Limbangan & 166.77 & Low \\
\hline Slawi & 794.17 & Moderate \\
\hline Darmaraja & 475.53 & Low \\
\hline Cibugel & 537.26 & Moderate \\
\hline Wado & 913.45 & Moderate \\
\hline Cadasngampar & 512.10 & Moderate \\
\hline Banyuresmi & 156.78 & Low \\
\hline
\end{tabular}

F. The vulnerability of Landslide Settlement Areas in Ci Manuk Upstream Watershed

The landslide vulnerability area in this study has resulted from the overlay of population density data and the building quality with landslide-prone areas. Therefore, the landslide vulnerability area has the same area and shape as the landslide-prone areas. Areas with high quality of building and low population density tend vulnerability to small landslides, and regions with low building quality and high population density tend vulnerability to high landslides [25]. Vulnerability to landslide levels was analyzed using descriptive spatial analysis. The landslide vulnerability area in Ci Manuk Upstream Watershed has a total area of 66.70 $\mathrm{km}^{2}$.

Fig. 6 shows the spread of low, moderate, and high landslide vulnerability reasonably evenly in the middle to the south or Upstream watershed. However, in the north (downstream) basin, it is more dominated by moderate landslide vulnerability areas and less dominated by low landslide vulnerability. Vulnerability areas are dominant in the central and southern parts $\left(27.93 \mathrm{~km}^{2}\right.$ or $\left.41.88 \%\right)$ because villages located in the Upstream watershed have relatively high population densities. In the north or downstream areas are dominated by areas that are vulnerable to low and moderate landslides. The villages there has a relatively low population density, thereby reducing vulnerability to landslides. Low-grade vulnerability areas have the smallest region, which is $18.22 \mathrm{~km}^{2}$ or $27.32 \%$.

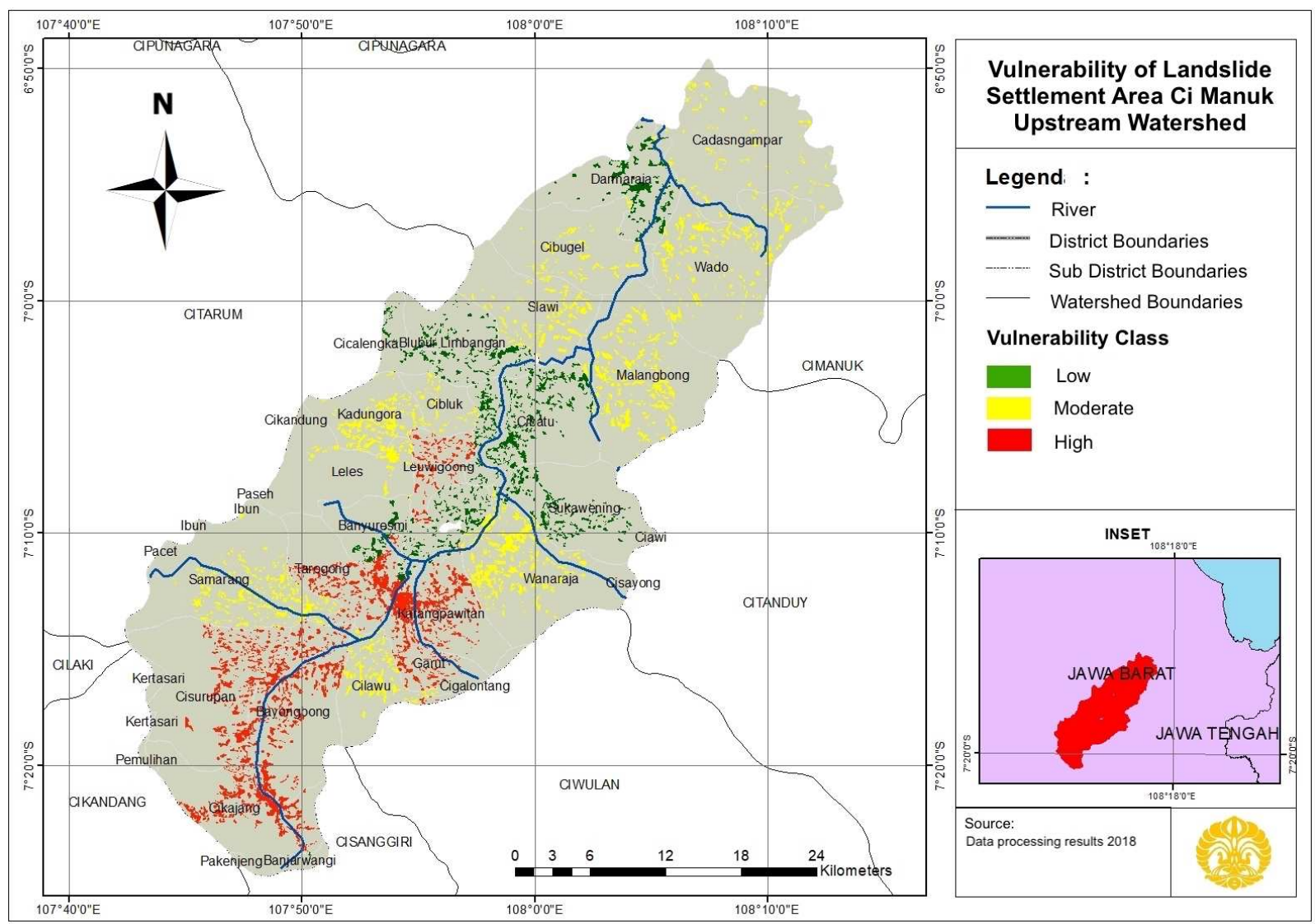

Fig. 6 Vulnerability of Landslide Settlement Area Ci Manuk Upstream Watershed 
The area of landslide vulnerabilities is presented in Table 6 .

TABLE VI

AREA AND PERCENTAGE of VULNERABILITy LANDSLIDE SETTLEMENT AREAS IN CI MANUK UPSTREAM WATERSHED

\begin{tabular}{|c|l|c|c|}
\hline No. & $\begin{array}{c}\text { Landslide } \\
\text { Vulnerability Class }\end{array}$ & $\begin{array}{c}\text { Area } \\
\left(\mathrm{km}^{2}\right)\end{array}$ & Percentage (\%) \\
\hline 1 & Low & 18.22 & 27.32 \\
\hline 2 & Moderate & 27.93 & 41.88 \\
\hline 3 & High & 20.54 & 30.80 \\
\hline Total & 66.70 & 100.00 \\
\hline
\end{tabular}

Distribution of landslide vulnerable settlement areas of $\mathrm{Ci}$ Manuk Upstream per village that is (1) Low: Pamekarsari, Sukaraja, Sukahaji, Sukasenang, Pananjung, Bagendit, Sukaratu, Kertajaya, Cibatu, Wanakerta, Sukawening, Sindangsuka; (2) Moderate: Cisaat, Cikembulan, Mekarbati, Hegarsari, Telagasari, Cangkuang, Mangkurakyat, Sukahati, Mekarmukti, Sukamukti, Margalaksana, Cintarasa, Cihuni, Wanaraja, Cinunuk, Sukahurip, Karangsari; (3) High: Girijaya, Cikajang, Padasuka, Cigedug, Sirnajaya, Cipaganti, Mekarjaya, Sukajaya, Bayongbong, Cibodas, Salakuray, Kotawetan, Suci, Jati, Sukajadi, Cimurah, Situgede, Karanganyar. Description of area with high landslide vulnerability level is captured by using Google Earth software in Cisurupan, Cipaganti Village which can be seen in Fig 7.

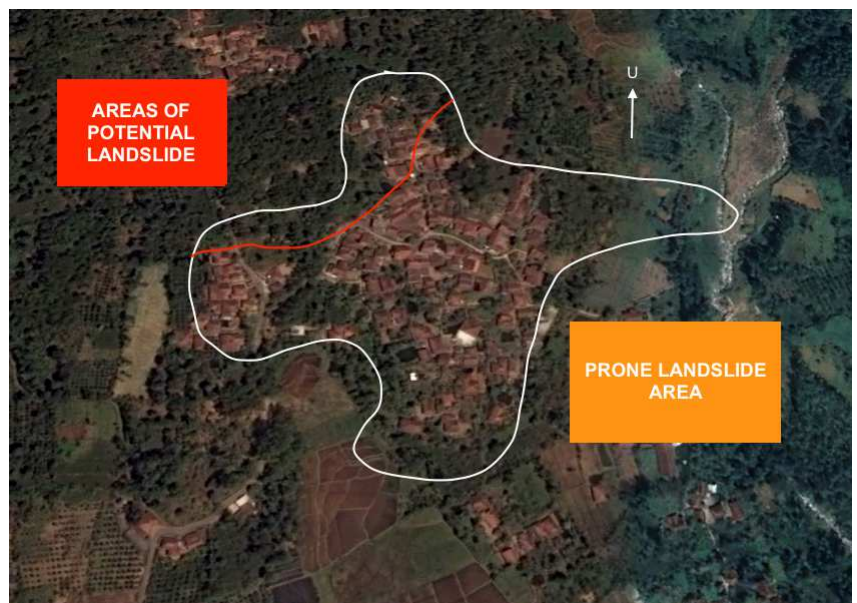

Fig. 7 High Landslide Vulnerability Area in Cisurupan, Cipaganti Village from Google Earth

\section{CONCLUSIONS}

Based on the modeling of SINMAP (Stability Index Mapping), indicating that $43.88 \%$ of the total area of the $\mathrm{Ci}$ Manuk Upstream watershed area is a potential landslide area. The results of landslide potential validation in $\mathrm{Ci}$ Manuk Upstream of 38 mudslide incidents that have occurred before, 31 occurrences are in the territory of potential landslides by the modeling of SINMAP. SINMAP modeling in Ci Manuk Upstream has an accuracy of $81.57 \%$.

The settlements area prone to high landslides in Ci Manuk Upstream watershed amounted to $19.04 \%$ or an area of $12.70 \mathrm{~km}^{2}$. The north or downstream of the basin, dominated by the area of vulnerable landslides with the class of high avalanche-prone, while in the south or upstream the watershed is dominated by landslide-prone areas with low prone type. The factors that make the region have a high level of prone because settlements are in the area of potential landslides.

$30.80 \%$ or $20.54 \mathrm{~km}^{2}$ is the vulnerability of the settlement areas in the high landslide area. Susceptible levels of landslides tend to increase from downstream to the upstream watershed. These levels are because the population in the downstream of the basin tends to be lower in density, so the low vulnerable level and the quality of buildings in downstream areas have the high quality of buildings.

\section{REFERENCES}

[1] BNPB, Indeks Rawan Bencana Indonesia, Jakarta: Badan Nasional Penanggulangan Bencana, 2017.

[2] Arsyad, Sitanala, Konservasi Tanah dan Air, Bandung: IPB Press, 2006.

[3] Arifin, Samsul, Carolila, Ita and Winarso, Cahol, "Implementasi Penginderaan Jauh dan SIG untuk Inventarisasi Daerah Rawan Bencana Longsor (Provinsi Lampung)", Jurnal Penginderaan Jauh, vol. 3, pp. 77-86, 2006.

[4] Kumajas, Mithel, "Inventarisasi dan Pemetaan Rawan Longsor Kota Manado - Sulawesi Utara", Forum Geografi, vol.20, pp. 190-197, 2006.

[5] Badan Perencanaan Pembangunan Daerah (Bappeda), Rencana Kerja Pemerintah Daerah (RKPD) Provinsi Jawa Barat, Bandung: Badan Perencanaan Pembangunan Daerah Provinsi Jawa Barat, 2008.

[6] Somantri, Lili, Kajian Mitigasi Bencana Longsor Lahan Dengan Menggunakan Teknologi Penginderaan Jauh. Jurnal Seminar Ikatan Geografi Indonesia, 2008.

[7] Balai Pengelola Daerah Aliran Sungai (BPDAS) Cimanuk-Citanduy, Kejadian Bencana Tanah Longsor di Kabupaten Garut, Garut: BPDAS, 2016.

[8] Nugroho, Sutopo Purwo, Evaluasi Penanggulangan Bencana 2015 dan Prediksi Bencana 2016, Jakarta: Badan Nasional Penanggulangan Bencana, 2016.

[9] Sulaiman, W.N.A, "Susceptibility of Shallow Landslide in Fraser Hill Catchment, Pahang Malaysia”, Journal of Enviroment Asia, pp. 66-72, 2010.

[10] Wang, Kuo-Lung, Development of shallow $1 \%$ seismic landslide potential map based on Newmark's displacement: the case study of Chi-Chi earthquake, Taiwan, Taiwan: Environmental Earth Sciences, 2009.

[11] Setiadi, Tedy, "Perancangan Sistem Informasi Geografis Pemetaan Daerah Rawan Tanah Longsor, Mitigasi dan Manajemen Bencana di Kabupaten Banjarnegara”, Jurnal Kesehatan Masyarakat, vol. 7, pp. 33-42, 2013.

[12] Deb, S.K., and El-Kadi A.I, "Susceptibility assessment of shallow landslides on Oahu, Hawaii, under extreme-rainfall events", Journal of Geomorphology, vol. 108, pp. 219-233, 2009.

[13] Andriono, Bagus, Wilayah Rentan Tanah Longsor di Sepanjang Alur Ci Tarik DA Ci Tarik Kabupaten Sukabumi, Depok: Universitas Indonesia, 2012.

[14] Wibowo, Agung, Identifikasi Wilayah Rentan Longsor di Kecamatan Cicalengka, Kabupaten Bandung, Depok: Universitas Indonesia, 2009.

[15] Triwahyuni, Lisa, Sobirin, and Ratna Saraswati, "Analisis Spasial Wilayah Potensi Longsor dengan Metode SINMAP dan SMORPH di Kabupaten Kulon Progo, Daerah Istimewa Yogyakarta”, Industrial Research Workshop and National Seminar, pp. 69-76, 2017.

[16] Pack, R.T., Tarboton, D.G., and Goodwin, C.N, A Stability Index Approach Terrain Stability Hazard Mapping. SINMAP User Manual, Utah State University, Vancouver: Forest Renewal British Columbia, 1998.

[17] Izhom, M. Baried, Kerentanan Wilayah Tanah Longsor di Daerah Aliran Ci Catih, Kabupaten Sukabumi, Jawa Barat, Depok: Universitas Indonesia, 2012.

[18] Nandi, Longsor, Bandung: Jurusan Pendidikan Geografi FPIPS UPI, 2007.

[19] Ringler, C, Mapping South African Farming Sector Vulnerability to Cilmate Change and Variability, Pretoria: International Food Policy Research Institute, 2009. 
[20] Klimes, Jan, "Analysis Of Preparatory Factors Of Landslides, Vsetínské Vrchy Highland, Czech Republic", Acta Research Reports, no. 17, pp. 47-53, 2008.

[21] Hadmoko, Danang Sri, Djati Mardiatno, and Fajar Siddik, Analisis Stabilitas Lereng untuk Zonasi Daerah Rawan Longsor di DAS Secang Kulonprogo dengan Menggunakan Model Deterministik, Jurnal Remote Sensing and GIS, 2009.

[22] Mubekti, "Mitigasi Daerah Rawan Tanah Longsor Menggunakan Teknik Pemodelan Sistem Informasi Geografis", Jurnal Teknik Lingkungan, vol. 9, pp. 121-129, 2008.
[23] Pack, R, SINMAP II: A Stability Index Approach To Tereain Stability Hazart Mapping, Utah: Utah State University, 2005.

[24] Sitorus, S, Pengembangan Lahan Berpenutupan Tetap sebagai kontrol Terhadap Faktor Resiko dan Bencana Longsor, Jakarta: Direktorat Jendral Penataan Ruang Departemen Pekerjaan Umum, 2006.

[25] Suranto, J.P, Kajian Pemanfaatan Lahan Pada Daerah Rawan Bencana Tanah Longsor di Gunungluruh, Cilongok, Banyumas, Semarang: Tesis Program Pascasarjana Magister Teknik Pembangunan Wilayah dan Kota UNDIP, 2008. 